\title{
Correlation of $\mathrm{Ca}^{2+}$ - and calmodulin-dependent protein kinase activity with secretion of insulin from islets of Langerhans
}

\author{
Jerry R. COLCA, ${ }^{*}$ Charles L. BROOKS, Michael LANDT and Michael L. MCDANIEL \\ Departments of Pathology and Pediatrics, Washington University School of Medicine, 660 South Euclid \\ Avenue, St. Louis, MO 63110, U.S.A.
}

(Received 20 December 1982/Accepted 8 March 1983)

\begin{abstract}
A $\mathrm{Ca}^{2+}$-activated and calmodulin-dependent protein kinase activity which phosphorylates predominantly two endogenous proteins of $57 \mathrm{kDa}$ and $54 \mathrm{kDa}$ was found in a microsomal fraction from islet cells. Half-maximal activation of the protein kinase occurs at approx. $1.9 \mu \mathrm{M}-\mathrm{Ca}^{2+}$ and $4 \mu \mathrm{g}$ of calmodulin $/ \mathrm{ml}(250 \mathrm{nM})$ for phosphorylation of both protein substrates. Similar phosphoprotein bands $(57 \mathrm{kDa}$ and $54 \mathrm{kDa})$ were identified in intact islets that had been labelled with $\left.{ }^{32} \mathbf{P}\right] \mathbf{P}_{\mathrm{i}}$. Islets prelabelled with $\left.{ }^{32} \mathrm{P}\right] \mathrm{P}_{1}$ and incubated with $28 \mathrm{~mm}$-glucose secreted significantly more insulin and had greater incorporation of radioactivity into the $54 \mathrm{kDa}$ protein than did islets incubated under basal conditions in the presence of $5 \mathrm{~mm}$-glucose. Thus the potential importance of the phosphorylation of these proteins in the regulation of insulin secretion is indicated both by activation of the protein kinase activity by physiological concentrations of free $\mathrm{Ca}^{2+}$ and by correlation of the phosphorylation of the substrates with insulin secretion in intact islets. Experiments undertaken to identify the endogenous substrates indicated that this calmodulin-dependent protein kinase may phosphorylate the $\alpha$-and $\beta$-subunits of tubulin. These findings suggest that $\mathrm{Ca}^{2+}$-stimulated phosphorylation of islet-cell tubulin via a membrane-bound calmodulin-dependent protein kinase may represent a critical step in the initiation of insulin secretion from the islets of Langerhans.
\end{abstract}

$\mathrm{Ca}^{2+}$ is required for insulin secretion from the islets of Langerhans (Grodsky \& Bennett, 1966). All known insulinogenic stimuli affect $\mathrm{Ca}^{2+}$ fluxes in intact islets, leading to an increase in the intracellular content of $\mathrm{Ca}^{2+}$ (Malaisse et al., 1978). For these reasons, it is generally assumed that intracellular $\mathrm{Ca}^{2+}$ concentrations represent a critical regulator of the secretory process. However, the mechanism by which cellular $\mathrm{Ca}^{2+}$ exerts its effects is poorly understood.

A good candidate for the transduction of a signal reflecting changes in $\mathrm{Ca}^{2+}$ concentration is the $\mathrm{Ca}^{2+}$-binding protein, calmodulin. Calmodulin binds $\mathrm{Ca}^{2+}$ ions at micromolar concentrations and subsequently alters the activities of several enzyme systems (Cheung, 1980). Calmodulin is present in high concentrations in the pancreatic islets (Sugden

Abbreviations used: SDS, sodium dodecyl sulphate; Hepes, 4-(2-hydroxyethyl)-1-piperazine-ethanesulphonic acid; Pipes, 1,4-piperazinediethanesulphonic acid.

* To whom reprint requests should be addressed. et al., 1979; Landt et al., 1982) and has been shown to alter such activities as adenylate cyclase (Valverde et al., 1979), cyclic nucleotide phosphodiesterase (Sugden \& Ashcroft, 1981), plasmamembrane $\left(\mathrm{Ca}^{2+}+\mathrm{Mg}^{2+}\right)$-ATPase (Kotagal et al., 1982), and a myosin light-chain kinase activity (MacDonald \& Kowluru, 1982) in islet-cell homogenates. $\mathrm{A} \mathrm{Ca}^{2+}$-activated and calmodulin-dependent protein kinase has been described in an insulin-secreting tumour (Schubart et al., 1980), and is similar to a membrane-bound protein kinase in adipose tissue (Landt \& McDonald, 1980). We have demonstrated a $\mathrm{Ca}^{2+}$-activated and calmodulin-dependent protein kinase activity in islets and have localized this activity to the microsomal fraction (Landt et al., 1982). This protein kinase activity was shown to phosphorylate an unidentified endogenous protein substrate of $57 \mathrm{kDa}$. A similar calmodulin-dependent protein kinase activity has been reported by Ashcroft and associates (Gagliardino et al., 1980; Harrison \& Ashcroft, 1982).

Our present studies have focused on further

Vol. 212 
characterization of this $\mathrm{Ca}^{2+}$-activated calmodulindependent protein kinase activity. We have also sought to correlate this protein kinase activity with insulin secretion in the intact islets, and to investigate the identity of the protein substrate.

\section{Experimental}

\section{Materials}

Male Wistar rats (180-250g) were purchased form Charles Rivers Laboratories (Wilmington, MA, U.S.A.) or male Sprague-Dawley rats (180$200 \mathrm{~g}$ ) were obtained from Sasco (O’Fallon, MO, U.S.A.). Calmodulin was prepared from rat brain (Charbonneau et al., 1979) or purchased from Calbiochem (La Jolla, CA, U.S.A.). These calmodulin stocks were compared and found to be equivalent by assay of $\mathrm{Ca}^{2+}$-stimulated phosphodiesterase activity (Watterson et al., 1976). [ $\gamma$ ${ }^{32}$ P]ATP was purchased from Amersham (Chicago, IL, U.S.A.). Ionophore A23187 was purchased from Calbiochem. $\left[{ }^{32} \mathrm{P}\right] \mathrm{P}_{1}$, Protosol and Aquasol II were from New England Nuclear (Boston, MA, U.S.A.). Sheep anti-tubulin antibody (affinity-chromatography-purified) was from CABBCO (Houston, TX, U.S.A.), and all other chemicals were reagent grade and purchased from Sigma Chemical Co. (St. Louis, MO, U.S.A.). Chromatographically purified bovine brain tubulin was a gift from Dr. L. A. Brown, St. Louis University.

\section{Isolation of pancreatic islets and islet-cell mem- branes}

Islets were isolated by collagenase digestion (Lacy \& Kostianovsky, 1967) and purified on dialysed Ficoll gradients (Shibata et al., 1976). The islets were then washed in Hanks solution and selected under a dissecting microscope. When subcellular fractionation of islets was performed, the islets were isolated under aseptic conditions and cultured overnight at $24^{\circ} \mathrm{C}$ (under air $/ \mathrm{CO}_{2}, 19: 1$ ) in culture medium 1066 (GIBCO, Grand Island, NY, U.S.A.) containing $8 \mathrm{~mm}$-glucose, $1 \%$ glutamine and $1 \%$ streptomycin and penicillin, with $10 \%(\mathrm{v} / \mathrm{v})$ foetalcalf serum.

Subcellular fractionation of islets was performed by the technique of Naber et al. (1980), with modifications as described previously (Colca et al., 1982). Where indicated, the protein kinase assays employed the microsomal fraction of the islet cells, which is enriched in protein kinase activity (Landt $e t$ al., 1982). This microsomal fraction contains a 2-3-fold enrichment of the endoplasmic-reticulum marker enzymes glucose 6-phosphatase and NADH: cytochrome $c$ reductase (Colca et al., 1982). This fraction is devoid of mitochondria and secretory granules, as judged by both biochemical (succinate:cytochrome $c$ reductase activity and extractable insulin content) and morphological criteria (Colca $e t$ al., 1982). Protein was assayed by using fluorescamine, with bovine serum albumin as standard (Orr et al., 1976).

\section{Protein kinase assays}

Protein kinase assays were performed as described previously (Landt et al., 1982). Briefly, incubations were performed in medium $(50 \mu \mathrm{l})$ containing $20-50 \mu \mathrm{g}$ of homogenate protein or 2-4 $\mu \mathrm{g}$ of microsomal protein, $50 \mathrm{~mm}$-Pipes ( $\mathrm{pH} 7.0$ at $\left.37^{\circ} \mathrm{C}\right), \quad 10 \mathrm{~mm}-\mathrm{MgCl}_{2}, 0.1 \mathrm{~mm}$-dithiothreitol, $0.2 \mathrm{mM}$-EGTA, with or without $1 \mu \mathrm{M}$-calmodulin and with or without $1 \mathrm{mM}^{-} \mathrm{CaCl}_{2}$. In some experiments, the concentrations of calmodulin and $\mathrm{Ca}^{2+}$ were varied. The incubation medium containing the indicated tissue was preincubated for $2 \mathrm{~min}$ at $37^{\circ} \mathrm{C}$, and the reaction was initiated by addition of 5-10 $\mu \mathrm{Ci}$ of $\left[\gamma^{-32} \mathrm{P}\right] \mathrm{ATP}$ (final concn. 5-10 $\mu \mathrm{M}-\mathrm{ATP}$ ) and terminated after $5-120 \mathrm{~s}$ by the addition of $25 \mu \mathrm{l}$ of $9 \%(w / v)$ SDS $/ 6 \%(w / v) ~ 2-m e r c a p t o e t h a n o l / 15 \%$ (v/v) glycerol (stop solution) and incubation in a boiling-water bath for $2 \mathrm{~min}$. Samples were then separated on $10 \%$-polyacrylamide/SDS slab gels $(6-15 \mathrm{~h}$ at $100 \mathrm{~V})$, stained for protein with Coomassie Blue, destained, and dried. After autoradiography, protein bands were cut from the gels, by using the exposed film as a guide. These bands were then hydrated $(0.25 \mathrm{ml}$ of water $)$, heated at $50^{\circ} \mathrm{C}$ in Protosol $(1 \mathrm{ml})$, and ${ }^{32} \mathrm{P}$ incorporation was quantified by liquid-scintillation counting.

In some experiments, designed to determine the identity of the endogenous phosphorylated protein substrates, chromatographically purified tubulin was added to protein kinase assays where the microsomal fraction was used as a source of the protein kinase activity. Briefly, tubulin was purified from calf brain by $\left(\mathrm{NH}_{4}\right)_{2} \mathrm{SO}_{4}$ fractionation, followed by DEAE-Sephadex batch elution and column chromatography with Sephadex G-25 (Lee, 1982). The purified tubulin was precipitated with $\mathrm{MgCl}_{2}$, and extensively dialysed against $1 \mathrm{M}$-sucrose $/ 10 \mathrm{mM}^{-} \mathrm{Na}_{2}$ $\mathrm{B}_{4} \mathrm{O}_{7} / 0.1 \mathrm{~mm}-\mathrm{GTP} / 0.5 \mathrm{~mm}-\mathrm{MgCl}_{2}, \mathrm{pH}$ 7.0. Other experimental protocols involved preincubation of the microsomal fraction with sheep anti-tubulin antibody $\left(30 \mathrm{~min}, 37^{\circ} \mathrm{C}\right)$ to bind endogenous tubulin. The antitubulin antibody was dialysed before use to remove the original borate buffer. Iodinated tubulin standards were used to verify that this preparation of antibody would bind tubulin under these experimental conditions.

\section{Intact-islet experiments}

Studies were performed with intact islets to determine if phosphorylation of these protein substrates occurred in intact cells, and whether this phosphorylation was associated with stimulated insulin secretion. In these studies, islets were isolated from $10-11$ rats and preincubated in incubation medium 
(pH 7.4) for $60 \mathrm{~min}$ at $37^{\circ} \mathrm{C}$. The incubation medium contained $5 \mathrm{mM}$-Hepes, $0.1 \%$ bovine serum albumin, $5 \mathrm{~mm}$-D-glucose, $115 \mathrm{~mm}-\mathrm{NaCl}, 24 \mathrm{~mm}-\mathrm{NaHCO}_{3}$, $5 \mathrm{~mm}-\mathrm{KCl}, 1 \mathrm{~mm}-\mathrm{MgCl}_{2}$ and $2.5 \mathrm{~mm}-\mathrm{CaCl}_{2}$. The preincubated islets were washed with fresh incubation medium and loaded with $400-600 \mu \mathrm{Ci}$ of $\left[{ }^{32} \mathrm{P}\right] \mathrm{P}_{\mathrm{i}}$ in $400 \mu \mathrm{l}$ of medium for $20 \mathrm{~min}$ at $37^{\circ} \mathrm{C}$. In initial experiments, islets were pre-labelled with $\left.{ }^{32} \mathrm{P}\right] \mathrm{P}_{1}$ for $0-90 \mathrm{~min}$. Longer loading periods increased background radioactivity, making it more difficult to demonstrate experimentally induced increases in phosphorylation of the protein bands of interest. Thus, for experiments presented, a $20 \mathrm{~min}$ $\left[{ }^{32} \mathrm{P}\right] \mathrm{P}_{1}$-loading period was used. The radiolabelled islets were washed extensively with incubation medium at $4{ }^{\circ} \mathrm{C}$ to remove residual $\left[{ }^{32} \mathrm{P}\right] \mathrm{P}_{1}$, and transferred to silicone-treated Petri plates; 100 islets were individually selected with a Pasteur pipette and placed in randomized $(10 \mathrm{~mm} \times 75 \mathrm{~mm})$ borosilicate culture tubes. The islet samples were maintained in a water bath at $4^{\circ} \mathrm{C}$ until the experiment was begun.

Experimental incubations were initiated by removal of the cold incubation medium and addition of $0.25 \mathrm{ml}$ of medium at $37^{\circ} \mathrm{C}$ containing experimental additions. The islets were incubated at $37^{\circ} \mathrm{C}$ under an atmosphere of $\mathrm{O}_{2} / \mathrm{CO}_{2}(19: 1)$ for the indicated times. The medium was then removed with the aid of a dissecting microscope and kept for insulin determinations. The islets were dissolved in $3 \% \mathrm{SDS} / 2 \%$ 2-mercaptoethanol/5\% glycerol $(70 \mu \mathrm{l})$, placed in a boiling-water bath for $2 \mathrm{~min}$, and then subjected to electrophoresis and autoradiography as described above. Immunoreactive insulin was quantified by the method of Wright et al. (1971). In experiments utilizing shorter incubation times, insulin secretion was not measured. In these experiments, incubations were performed in $50 \mu \mathrm{l}$ of medium and were terminated after the indicated times by addition of $25 \mu \mathrm{l}$ of stop solution. The samples were then processed for liquid-scintillation counting as described above. All experiments were performed in triplicate.

\section{Statistical analysis of the data}

Statistical evaluation of the data was by randomized blocks design (intact-islet experiments), single classification analysis of variance, or Student's $t$ test, as appropriate.

\section{$\mathrm{Ca}^{2+}$ concentrations}

Free $\mathrm{Ca}^{2+}$ concentrations were determined by calculation of the $\mathrm{Ca}^{2+}$ chelated by EGTA, which was added to buffer the final $\mathrm{Ca}^{2+}$ concentrations. Total $\mathrm{Ca}^{2+}$ concentration in stock solutions was confirmed by atomic-absorption spectrophotometry. The calculation of free $\mathrm{Ca}^{2+}$ concentration assumed an association constant for Ca-EGTA of $10^{6.84}$ at $\mathrm{pH} 7.0$ and was determined by the method of Schatzmann (1973). The calculated $\mathrm{Ca}^{2+}$ concentration was confirmed by measurement with an Orion $93-20 \mathrm{Ca}^{2+}$-selective electrode in conjunction with an Orion 811 microprocessor (Simons, 1982).

\section{Results}

\section{Further characterization of protein kinase activity}

Our previous studies described a $\mathrm{Ca}^{2+}$-activated calmodulin-dependent protein kinase that phosphorylated a $57 \mathrm{kDa}$ islet-cell protein band. Longer electrophoretic separation ( $15 \mathrm{~h}$ rather than $6 \mathrm{~h}$ ) of the phosphoproteins demonstrated that this band was in fact at least two separate protein bands migrating at relative molecular weights of $\mathbf{5 7 0 0 0}$ and 54000 .

The $\mathrm{Ca}^{2+}$-sensitivity of this protein kinase activity with regard to the phosphorylation of these proteins was investigated by using the islet-cell microsomal fraction. This subcellular fraction served as a source of both kinase and endogenous substrates. These assays were terminated after an incubation period of $5 \mathrm{~s}$ such that protein phosphorylation would reflect the rate of enzyme activity rather than the availability of the endogenous substrates (Landt et al., 1982). In the presence of calmodulin $(1 \mu \mathrm{M})$ the rate of phosphorylation of both the $57 \mathrm{kDa}$ and $54 \mathrm{kDa}$ protein bands was stimulated by free $\mathrm{Ca}^{2+}$ concentrations in the micromolar range (Fig. 1). However, in the absence of added calmodulin, the addition of $\mathrm{Ca}^{2+}(0.1 \mu \mathrm{M}-1 \mathrm{mM})$ did not affect the rate of protein kinase activity (results not shown). The activation of protein kinase activity by $\mathrm{Ca}^{2+}$ was saturable with respect to $\mathrm{Ca}^{2+}$ concentration and similar for the phosphorylation of both protein bands. In three experiments, half-maximal activation of protein kinase activity occurred at $1.99 \pm 0.87 \mu \mathrm{M}-$ and $1.92 \pm 0.78 \mu \mathrm{M}-\mathrm{Ca}^{2+}$ for the $57 \mathrm{kDa}$ and $54 \mathrm{kDa}$ protein bands respectively.

The calmodulin requirement for the phosphorylation of these protein bands by the islet-cell microsomal protein kinase activity was investigated in similarly designed experiments. In the absence of $\mathrm{Ca}^{2+}$ and in the presence of $200 \mu \mathrm{M}-$ EGTA, calmodulin $(2-40 \mu \mathrm{g} / \mathrm{ml})$ did not affect the rate of phosphorylation of either protein band (results not shown). The addition of calmodulin in the presence of $800 \mu \mathrm{M}$ free $\mathrm{Ca}^{2+}$ produced a concentrationdependent increase in protein kinase activity (Fig. 2). Half-maximal activation of the rate of phosphorylation occurred at $4.37 \pm 1.09$ and $4.05 \pm 0.40 \mu \mathrm{g}$ of calmodulin $/ \mathrm{ml}$ for the $57 \mathrm{kDa}$ and $54 \mathrm{kDa}$ protein bands respectively $(n=3)$. Maximal stimulation of the rate of phosphorylation occurred at approx. $10 \mu \mathrm{g}$ of calmodulin $/ \mathrm{ml}(590 \mathrm{~nm})$.

Cyclic AMP did not affect the protein kinase activity present in the islet-cell microsomal fraction. In these studies, protein kinase assays were per- 


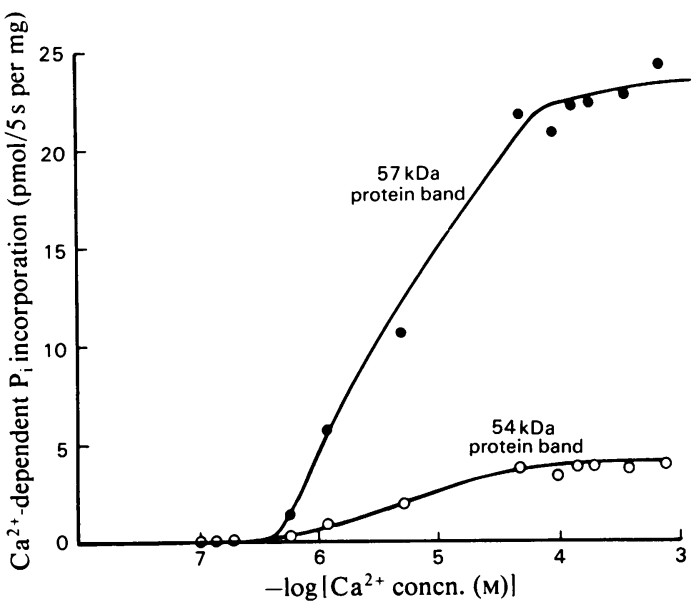

Fig. 1. Dependence of islet-cell protein kinase activity on free $\mathrm{Ca}^{2+}$

The rate of calmodulin-dependent protein kinase activity was measured in $5 \mathrm{~s}$ assays as described in the Experimental section. The islet-cell microsomal fraction was utilized as the source for both protein kinase and endogenous substrates. Free $\mathrm{Ca}^{2+}$ concentrations were maintained with $0.2 \mathrm{mM}$-EGTA as described in the Experimental section. $\mathrm{Ca}^{2+}$.

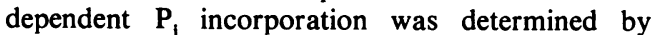
subtracting $\left[{ }^{32} \mathrm{P}\right] \mathrm{P}_{1}$ incorporated into the $57 \mathrm{kDa}$ band $(0.94 \pm 0.1 \mathrm{pmol} / \mathrm{mg}$ per $5 \mathrm{~s})$ and $54 \mathrm{kDa}$ band $(0.67 \pm 0.07 \mathrm{pmol} / \mathrm{mg}$ per $5 \mathrm{~s})$ in the absence of $\mathrm{Ca}^{2+}$. The results are those obtained with $1 \mu \mathrm{M}$-calmodulin in a representative experiment $(n=3)$.

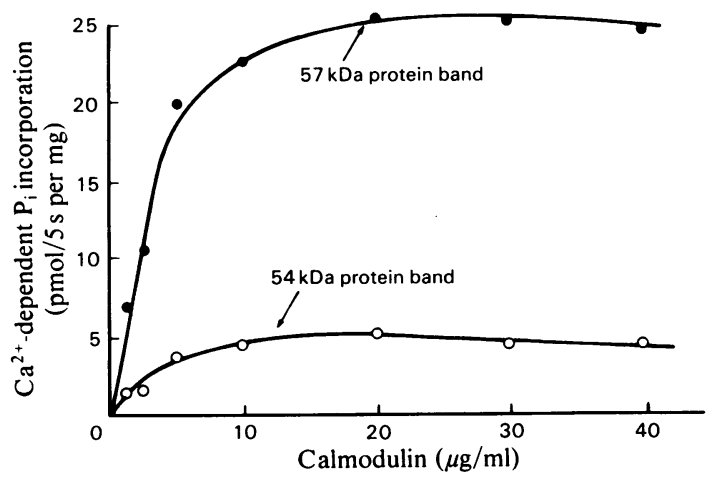

Fig. 2. Calmodulin-dependence of islet-cell protein kinase activity

The rate of protein kinase activity was measured as described in the Experimental section. The islet-cell microsomal fraction was used as a source of both protein kinase activity and endogenous substrates. Results show the rate of protein phosphorylation of the $57 \mathrm{kDa}$ and $54 \mathrm{kDa}$ substrates in the presence of $800 \mu \mathrm{M}$ free $\mathrm{Ca}^{2+}$ for a representative experiment $(\mathrm{n}=3)$ formed with $10 \mu \mathrm{M}^{-}$or $100 \mu \mathrm{M}$-cyclic AMP and the phosphodiesterase inhibitor theophylline $(1 \mathrm{mM})$, in $5 \mathrm{~s}$ incubations $(5 \mu \mathrm{M}-\mathrm{ATP})$ and in $2 \mathrm{~min}$ incubations $(20 \mu \mathrm{M}-\mathrm{ATP})$. In no case $(n=3)$ did cyclic AMP affect the phosphorylation of the $57 \mathrm{kDa}$ or $54 \mathrm{kDa}$ protein bands (results not shown).

\section{Intact-islet experiments}

To determine whether phosphorylation of the $57 \mathrm{kDa}$ and $54 \mathrm{kDa}$ protein bands occurs in intact islets and if such phosphorylation could be correlated with insulin secretion, intact islets were incubated with $\left[{ }^{32} \mathrm{P}\right] \mathrm{P}_{\mathrm{i}}$ to label endogenous pools of ATP. After experimental incubations to stimulate the rate of insulin secretion, the islets were dissolved in SDS and subjected to electrophoresis as described in the Experimental section. Parallel lanes on the polyacrylamide slab gels contained cell-free protein kinase incubations with or without $\mathrm{Ca}^{2+}$ and calmodulin as an internal marker for these protein substrates. The intact islets were found to phosphorylate proteins that had the same electrophoretic mobilities as did the $57 \mathrm{kDa}$ and $54 \mathrm{kDa}$ protein substrates (Fig. 3). In experiments using intact islets, the $54 \mathrm{kDa}$ protein band was more heavily phosphorylated than was the $57 \mathrm{kDa}$ band, whereas in the cell-free protein kinase assays phosphorylation of the $57 \mathrm{kDa}$ band was more prominent (Fig. 3).

Islets that were prelabelled with $\left[{ }^{32} \mathrm{P}\right] \mathrm{P}_{1}$ and incubated for $5 \mathrm{~min}$ in the presence of $28 \mathrm{mM}$ D-glucose secreted significantly more insulin into the medium $(P<0.05)$ and had a significantly greater incorporation of $\left[{ }^{32} \mathrm{P}\right] \mathrm{P}_{\mathrm{i}}$ into the $54 \mathrm{kDa}$ protein band than did islets incubated with $5 \mathrm{mM}$-D-glucose $(P<0.05$; Fig. 4). Although there was a trend toward an increase in $\left.{ }^{32} \mathrm{P}\right] \mathrm{P}_{1}$ incorporation into the $57 \mathrm{kDa}$ protein band at the higher glucose concentration, this effect was not statistically significant $(P>0.05)$. The effect of $28 \mathrm{~mm}$-glucose was more pronounced in the presence of $5 \mathrm{mM}$-theophylline, a known potentiator of glucose-induced insulin secretion. In the absence of extracellular $\mathrm{Ca}^{2+}$, glucoseinduced insulin secretion did not occur, and $28 \mathrm{mM}$ glucose decreased, rather than increased, the phosphorylation of the $54 \mathrm{kDa}$ protein band $(P<0.05)$.

In contrast with results obtained in $5 \mathrm{~min}$ experiments, incubation of prelabelled islets for $30 \mathrm{~s}$ in medium containing $28 \mathrm{~mm}$-glucose did not affect phosphorylation of the protein bands (results not shown). When the islets were incubated for various times with $28 \mathrm{~mm}$-glucose rather than $5 \mathrm{~mm}$-glucose (without theophylline) the maximum stimulation of the phosphorylation of the $54 \mathrm{kDa}$ protein band occurred at $3 \mathrm{~min}$ (Fig. 5). Under these conditions and incubation times, there was no detectable stimulation of $\left[{ }^{32} \mathrm{P}\right] \mathrm{P}_{\mathrm{i}}$ incorporation into the $57 \mathrm{kDa}$ band.

A 5 min incubation of prelabelled islets with the 


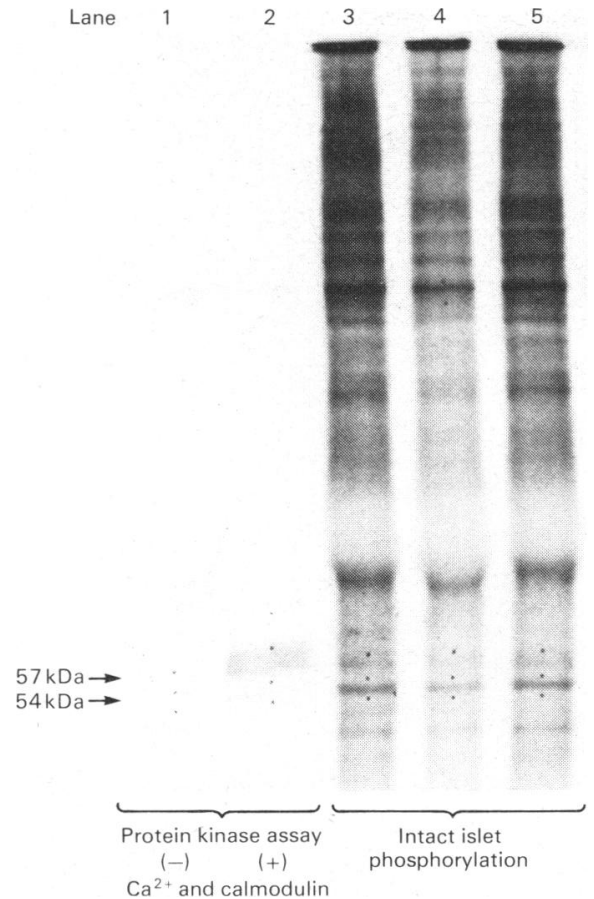

Fig. 3. Autoradiogram of phosphorylation of $57 \mathrm{kDa}$ and $54 \mathrm{kDa}$ proteins in intact islets and protein kinase assays

Protein kinase assays with islet-cell homogenates and intact-islet phosphorylation experiments were performed as described in the Experimental section. Lanes 1 and 2 show the effect of $\mathrm{Ca}^{2+}$ and calmodulin ( $1 \mathrm{mM}$ and $1 \mu \mathrm{M}$ respectively) on protein kinase activity. Lanes 3-5 show the phosphorylation of proteins in this molecular-weight region that occur in intact islets. The $57 \mathrm{kDa}$ and $54 \mathrm{kDa}$ protein bands were marked with pin holes by using the exposed film as a guide, and then cut from the gel for measurement of radioactivity.

$\mathrm{Ca}^{2+}$-ionophore A23187 $(10 \mu \mathrm{M})$ under otherwise standard conditions as described in the Experimental section also produced a modest increase in the ${ }^{32} \mathrm{P} \mid \mathrm{P}_{\mathrm{i}}$ incorporated into the islet-cell proteins. In each of four experiments, $10 \mu \mathrm{M}-\mathrm{A} 23187$ increased the phosphorylation of the $57 \mathrm{kDa}(14 \pm 3 \%)$ and $54 \mathrm{kDa}(16 \pm 8 \%)$ protein bands $(P<0.05)$.

\section{Identification of the protein substrates}

The islet-cell protein bands that were phosphorylated by the $\mathrm{Ca}^{2+}$-and calmodulin-dependent protein kinase had electrophoretic mobilities on $10 \%$-polyacrylamide gels that were indistinguishable from those of the $\alpha$ - and $\beta$-subunits of chromatographically purified brain tubulin. To determine if the tubulin subunits could serve as substrates for the islet-cell protein kinase, tubulin was added to protein kinase assays that used the islet-cell microsomal fraction as a source of the
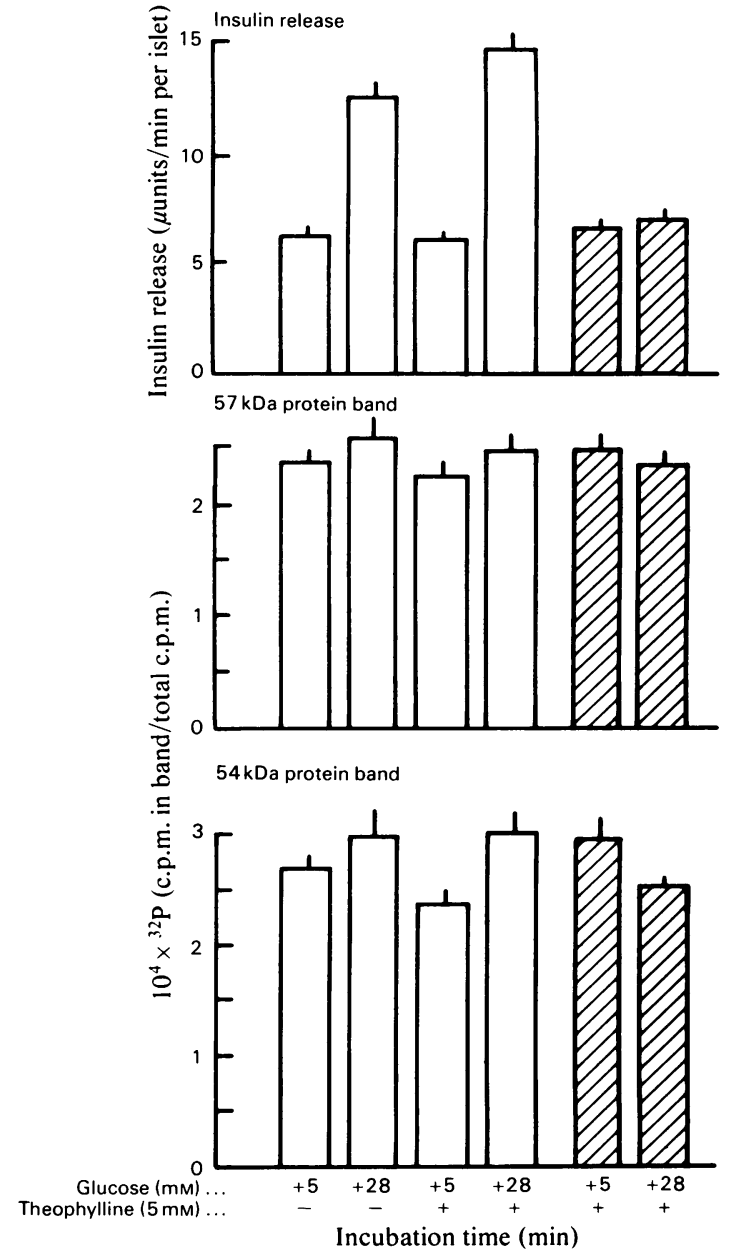

Fig. 4. Effect of glucose and theophylline on phosphorylation of $57 \mathrm{kDA}$ and $54 \mathrm{kDa}$ protein bands and on insulin secretion in intact islets

Islets were loaded with [ $\left.{ }^{32} \mathrm{P}\right] \mathrm{P}$, to label endogenous ATP pools as described in the Experimental section. Then $5 \mathrm{~min}$ incubations with islets were performed in incubation medium containing $5 \mathrm{~mm}-$ or $28 \mathrm{~mm}$ glucose with or without $5 \mathrm{~mm}$-theophylline as described in the Experimental section. Glucose (28 mM) significantly stimulated phosphorylation of the $54 \mathrm{kDa}$ protein $(P<0.05)$. Incubations were also performed in the absence of $\mathrm{Ca}^{2+}(\mathbb{Z})$. Radioactivity (c.p.m.) in each band is normalized by consideration of the total radioactivity contained in the 100 islets in each sample $(n=9)$.

enzyme. Assays were performed at time periods greater than $15 \mathrm{~s}$ such that the substrate concentration would become rate-limiting. Addition of tubulin to these kinase assays resulted in a significant increase in $\left.{ }^{32} \mathrm{P}\right] \mathrm{P}_{1}$ incorporated into the $57 \mathrm{kDa}$ and $54 \mathrm{kDa}$ protein bands, whereas tubulin added in the absence of islet-cell protein was not phos- 


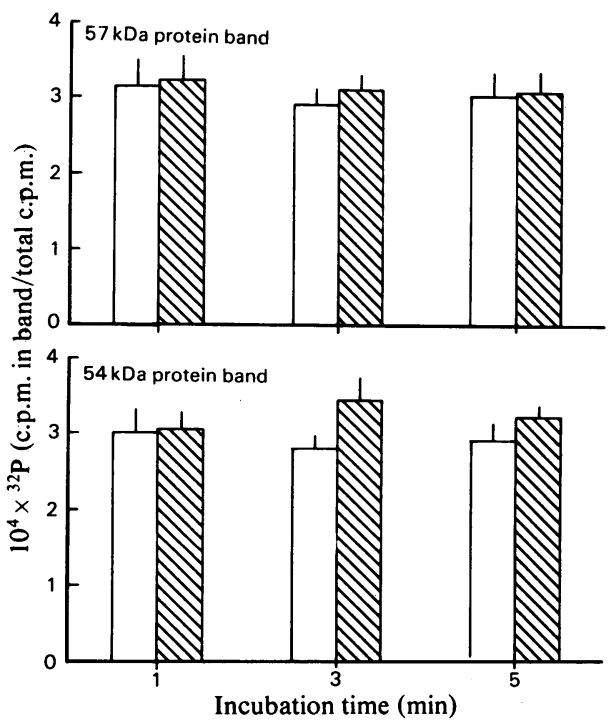

Fig. 5. Effect of glucose on phosphorylation of $57 \mathrm{kDa}$ and $54 \mathrm{kDa}$ protein bands in intact islets incubated for various times

Islets were loaded with [ $\left.{ }^{32} \mathrm{P}\right] \mathrm{P}_{1}$ to label endogenous ATP pools as described in the Experimental section. Experimental incubations with islets containing ( $\square$ ) $5 \mathrm{mM}$ - or $(\mathbb{\$}) 28 \mathrm{~mm}$-glucose were terminated after 1,3 or $5 \mathrm{~min}$ [ $28 \mathrm{~mm}$-glucose increased phosphorylation of the $54 \mathrm{kDa}$ band $(P<\overline{0.05})]$. Data represent means \pm S.E.M. for four experiments performed in triplicate. Radioactivity (c.p.m.) per band was normalized as described in Fig. 4.

phorylated (Fig. 6). Furthermore, phosphorylation of exogenous tubulin was stimulated by the addition of $\mathrm{Ca}^{2+}$ and calmodulin. In 30 s assays, the $\mathrm{Ca}^{2+}$ and calmodulin-dependent phosphorylation of the subunit of tubulin migrating with the $57 \mathrm{kDa}$ band was more pronounced $(P<0.05)$ than that for the tubulin subunit migrating with the $54 \mathrm{kDa}$ band $(P>0.05)$. These results indicated that the tubulin subunits could serve as substrates for the islet-cell protein kinase, and that phosphorylated tubulin (as well as non-phosphorylated tubulin) had the same electrophoretic mobility as the endogenous $57 \mathrm{kDa}$ and $54 \mathrm{kDa}$ substrates.

To determine if the endogenous substrates for the islet-cell protein kinase activity may in fact be $\alpha$ - and $\beta$-tubulin, the islet-cell microsomal fraction was pretreated with anti-tubulin antibody before the assay of protein kinase activity. Pretreatment of the islet-cell microsomal fraction (4-5 $\mu \mathrm{g}$ of microsomal protein; $13-15 \mu \mathrm{g}$ of antibody) for $30 \mathrm{~min}$ at $37^{\circ} \mathrm{C}$ decreased the subsequent $\mathrm{Ca}^{2+}$ - and calmodulindependent phosphorylation of the $57 \mathrm{kDa}$ and $54 \mathrm{kDa}$ protein bands by $79 \pm 6$ and $71 \pm 7 \%$ respectively, as measured in 30 s assays $(n=3)$. This effect of anti-tubulin antibody was reversed by pretreatment of the antibody at $100^{\circ} \mathrm{C}$ for $10 \mathrm{~min}$ (Fig. 7). Although heat treatment under these conditions did not totally destroy the antibody, this treatment served to decrease the antibody-induced inhibition of the phosphorylation of the $57 \mathrm{kDa}$ band by $50-70 \%$ and that of the $54 \mathrm{kDa}$ band by $80-100 \%$. Control sheep immunoglobulin $G$ was without effect (result not shown).

Experiments were undertaken to determine whether the phosphorylated endogenous substrates could be precipitated with tubulin antibody. After the standard protein kinase assay, the islet-cell microsomal fraction was treated with $1 \%$ Triton $\mathrm{X}-100$ and $1 \%$ deoxycholate and then incubated with sheep anti-tubulin and goat anti-(sheep immunoglobulin) serum. To minimize dephosphorylation during the antibody treatment, incubations were performed in the presence of $10 \mathrm{~mm}$-fluoride and $10 \mathrm{~mm}$-EGTA for $30 \mathrm{~min}$ at $37^{\circ} \mathrm{C}$. In four experiments the anti-tubulin antibody precipitated $555 \pm 100$ and $142 \pm 30$ c.p.m. of $\mathrm{Ca}^{2+}$ and calmodulin-stimulated ${ }^{32} \mathrm{P}$ incorporated into the $57 \mathrm{kDa}$ and $54 \mathrm{kDa}$ protein bands respectively. This 


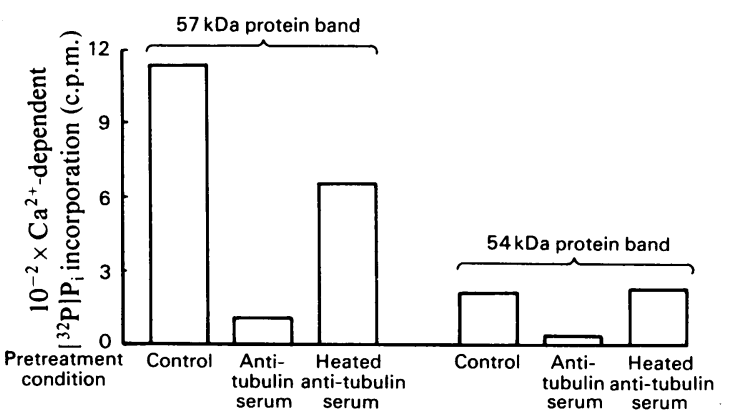

Fig. 7. Effect of anti-tubulin serum on protein kinase activity

Islet-cell microsomal protein was pretreated with control buffer, sheep anti-tubulin serum, or heattreated anti-tubulin serum for $30 \mathrm{~min}$ at $37^{\circ} \mathrm{C}$. Protein kinase assays were then initiated after addition of pretreated membranes and terminated after $30 \mathrm{~s}$ as described in the Experimental section. Results are from a representative experiment $(n=4)$.

represented a significant increase of the precipitation of ${ }^{32} \mathrm{P}$ relative to that which occurred in control tubes that were incubated with non-specific antibody $(P<0.05$, paired $t$ test). However, blank tubes incubated in the absence of specific antibody did contain significant radioactivity above background $(274 \pm 72$ and $91 \pm 32$ c.p.m. in $57 \mathrm{kDa}$ and $54 \mathrm{kDa}$ regions respectively), indicating that there was incomplete solubilization or reaggregation of the membranes during the antibody treatment.

\section{Discussion}

These studies have expanded our previous observation that pancreatic islets contain a membranebound calmodulin-dependent protein kinase activity (Landt et al., 1982), and support the hypothesis that the $\mathrm{Ca}^{2+}$-activated phosphorylation of endogenous proteins by this kinase activity may play a role in the regulation of insulin secretion.

The concentration of $\mathrm{Ca}^{2+}$ required for halfmaximal activation of the islet-cell protein kinase $(1-3 \mu \mathrm{M})$ is consistent with the possibility that this protein kinase is activated by increased $\mathrm{Ca}^{2+}$ concentrations that occur during the stimulation of insulin secretion. Other evidence indicates that $\mathrm{Ca}^{2+}$ concentrations in islets increase after treatment with insulinotropic agents (Wollheim \& Sharp, 1981) and may attain micromolar values. In permeabilized islets (Yaseen et al., 1982), micromolar free $\mathrm{Ca}^{2+}$ concentrations are required to stimulate insulin secretion. We have shown that the islet-cell microsomal fraction, in which this protein kinase activity is located, also contains an active $\mathrm{Ca}^{2+}$-sequestering activity that has an affinity for $\mathrm{Ca}^{2+}$ in this concentration range, i.e. 1-3 $\mu \mathrm{M}$ (Colca et al., 1982). The calmodulin requirement for this enzyme activity is similar to the calmodulin requirement for a similar membrane-bound protein kinase that was discovered in adipocytes (Landt \& McDonald, 1980).

It appears that this calmodulin-dependent protein kinase activity in the islet-cell microsomal fraction is not regulated by cyclic AMP. Ashcroft and colleagues (Gagliardino et al., 1980; Harrison \& Ashcroft, 1982) have also described a calmodulinstimulated phosphorylation of an endogenous protein band $(53-55 \mathrm{kDa})$ in an islet-cell homogenate. These investigators have reported that the phosphorylation of this protein band in islet-cell homogenates was increased by cyclic AMP (Harrison \& Ashcroft, 1982). We have also found that cyclic AMP enhanced the phosphorylation of the $57 \mathrm{kDa}$ protein band in assays which used the whole islet homogenate. Thus $10 \mu \mathrm{M}$-cyclic AMP and $5 \mathrm{~mm}$ theophylline produced a $78 \pm 24 \%$ increase in the rate of phosphorylation of the $57 \mathrm{kDa}$ protein band $(P<0.05)$ and a $35 \pm 4 \%$ decrease in the rate of phosphorylation of the $54 \mathrm{kDa}$ protein band ( $P<0.05 ; n=3,5 \mathrm{~s}$ assays). Similar results were obtained in protein kinase assays that were incubated for $2 \mathrm{~min}$, but the magnitude of the effects was less (results not shown). At present, it is not clear whether the differential effect of cyclic AMP on protein phosphorylation patterns in the homogenate as compared with the microsomal fraction indicates the presence of an additional protein kinase activity and/or substrates that is/are eliminated in the latter fraction.

Both the $57 \mathrm{kDa}$ and $54 \mathrm{kDa}$ phosphoproteins were found to occur in intact islets. The increase in phosphorylation of the $54 \mathrm{kDa}$ protein produced by glucose in intact-cell studies was correlated with stimulation of insulin secretion and supports the contention that the calmodulin-dependent protein kinase activity is involved in the insulin secretory response. As expected, removal of extracellular $\mathrm{Ca}^{2+}$ prevented glucose-induced insulin secretion and the glucose-induced increase in the phosphorylation of this protein. The paradoxical decrease in phosphorylation of the $54 \mathrm{kDa}$ protein band produced by glucose in the absence of extracellular $\mathrm{Ca}^{2+}$ may result from the redistribution of remaining cellular $\mathrm{Ca}^{2+}$. Glucose is thought to affect $\mathrm{Ca}^{2+}$ metabolism at several $\beta$-cell loci (Wollheim \& Sharp, 1981). The involvement of $\mathrm{Ca}^{2+}$ in this cellular response is also supported by the increase in phosphorylation of these proteins caused by the $\mathrm{Ca}^{2+}$ ionophore A23187.

Suzuki et al. (1981) have shown that elevated concentrations of glucose increased the steady-state incorporation of ${ }^{32} \mathrm{P} \mid \mathrm{P}_{i}$ into at least six islet-cell phosphoproteins. However, it is not clear whether 
these results reflect an increase in protein kinase activity or an increase in $\left.{ }^{32} \mathrm{P}\right] \mathrm{P}_{\mathrm{i}}$ uptake from the incubation medium, since these studies were done in the continued presence of $\left.{ }^{32} \mathrm{P}\right] \mathrm{P}_{\mathrm{i}}$ in the medium. The present studies were performed with islets that were extensively washed and free of external radiolabel. In the present experiments, total ${ }^{32} \mathrm{P}$ content was not affected detectably by the experimental treatments (results not shown). Although the present technique rules out the participation of $\left[{ }^{32} \mathrm{P}\right] \mathrm{P}_{1}$ uptake in the interpretation of the results, an increase in ATP synthesis by the experimental glucose concentration (Ashcroft et al., 1973) would decrease the specific radioactivity of the ATP pools and impart a negative bias to the results. These experiments with intact islets are also limited technically by the high background radioactivity that may obscure small changes in $\left[{ }^{32} \mathrm{P}\right] \mathrm{P}_{1}$ incorporation into specific protein bands. This problem may be circumvented in future experiments by immunoprecipitation of the endogenously phosphorylated substrates with antitubulin antibody.

Cell-free experiments favour the hypothesis that the major substrates for the $\mathrm{Ca}^{2+}$ - and calmodulindependent protein kinase may be the $\alpha$ - and $\beta$-subunits of tubulin. This conclusion is supported, since: (1) the electrophoretic mobilities of the $57 \mathrm{kDa}$ and $54 \mathrm{kDa}$ protein substrates are identical with those of the subunits of tubulin; (2) tubulin added to the islet-cell protein kinase assays augmented the phosphorylation of the $57 \mathrm{kDa}$ and $54 \mathrm{kDa}$ bands, in a $\mathrm{Ca}^{2+}$ - and calmodulin-sensitive manner; (3) pretreatment of the islet-cell microsomal fraction with anti-tubulin antibody greatly diminished the subsequent protein kinase activity; and (4) the endogenous phosphorylated substrates could be immunoprecipitated by incubation with anti-tubulin antibody. Also, incubation of the endogenously phosphorylated protein substrates with anti-tubulin antibody at $37^{\circ} \mathrm{C}$ significantly decreased the rate of dephosphorylation of these substrates in the absence of fluoride and EGTA (results not shown).

Burke \& DeLorenzo (1981) have also presented evidence that brain cytosol contains a $\mathrm{Ca}^{2+}+$ calmodulin-dependent protein kinase activity that can phosphorylate the $\alpha$ - and $\beta$-subunits of tubulin. They have further postulated that this calmodulindependent protein kinase system may be directly involved in neurotransmitter release (DeLorenzo, 1981). The characteristics of the brain enzyme with regard to $\mathrm{Ca}^{2+}$ requirement (half-maximal, $0.8 \mu \mathrm{M}$ ) and calmodulin-sensitivity (half-maximal, $4 \mu \mathrm{g} / \mathrm{ml}$ ) (Burke \& DeLorenzo, 1981) are similar to those described for the islet enzyme in the present study.

Although the significance of our findings with regard to microtubule function in islets is not clear, calmodulin is known to have effects on microtubule assembly in vitro. Calmodulin has been reported to inhibit microtubule assembly (Marcum et al., 1978; Nishida et al., 1979), and under certain conditions may increase microtubule assembly (Lee $\&$ Wolff, 1982). Microtubules are thought to play a critical role in the release process for insulin secretory granules from the $\beta$-cell (Lacy et al., 1968, 1972; Malaisse et al., 1971). Thus, if increases in cellular $\mathrm{Ca}^{2+}$ affect microtubule function in the $\beta$-cell by phosphorylation of tubulin via calmodulindependent protein kinase, this may represent an important transduction of the intracellular $\mathrm{Ca}^{2+}$ signal produced by insulinotropic agents such as glucose.

We thank Barbara E. Miller, C. Joan Fink and Deirdre Buscetto for excellent technical assistance. This work was supported in part by U.S. Public Health Service grants AM06181 and AM28233. J. R. C. is a recipient of a Juvenile Diabetes Foundation Fellowship.

\section{References}

Ashcroft, S. J. H., Weerasinghe, L. C. C. \& Randle, P. J. (1973) Biochem. J. 132, 223-231

Burke, B. E. \& DeLorenzo, R. J. (1981) Proc. Natl. Acad. Sci. U.S.A. 78, 991-995

Charbonneau, H., McRorie, R. A. \& Cormier, M. J. (1979) Fed. Proc. Fed. Am. Soc. Exp. Biol. 38, 232

Cheung, W. Y. (1980) Science 207, 19-27

Colca, J. R., McDonald, J. M., Kotagal, N., Patke, C., Fink, C. J., Greider, M., Lacy, P. E. \& McDaniel, M. L. (1982) J. Biol. Chem. 257, 7223-7228

DeLorenzo, R. J. (1981) Cell Calcium 2, 365-385

Gagliardino, J. J., Harrison, D. E., Christie, M. R., Gagliardino, E. E. \& Ashcroft, S. J. H. (1980) Biochem. J. 192, 919-927

Grodsky, G. M. \& Bennett, L. L. (1966) Diabetes 15, 910-913

Harrison, D. E. \& Ashcroft, S. J. H. (1982) Biochim. Biophys. Acta 714, 313-319

Kotagal, N., Patke, C., Landt, M., McDonald, J. M., Colca, J. R., Lacy, P. \& McDaniel, M. (1982) FEBS Lett. 137, 249-252

Lacy, P. E. \& Kostianovsky, M. (1967) Diabetes 16, 35-39

Lacy, P. E. \& Howell, S. L., Young, D. A. \& Fink, C. J. (1968) Nature (London) 219, 1177-1179

Lacy, P. E., Walker, M. M. \& Fink, C. J. (1972) Diabetes 21, 987-998

Landt, M. \& McDonald, J. M. (1980) Biochem. Biophys. Res. Commun. 93, 881-888

Landt, M., McDaniel, M. L., Bry, C. G., Kotagal, N., Colca, J. R., Lacy, P. E. \& McDonald, J. M. (1982) Arch. Biochem. Biophys. 213, 148-154

Lee, J. C. (1982) Methods Cell Biol. 24, 9-49

Lee, Y. C. \& Wolff, J. (1982) J. Biol. Chem. 257, 6303-6310

MacDonald, M. J. \& Kowluru, A. (1982) Diabetes 31, $566-570$

Malaisse, W. J., Malaisse-Lagae, F., Walker, M. M. \& Lacy, P. E. (1971) Diabetes 20, 257-265 
Malaisse, W. J., Herchuelz, A., Devis, G., Somers, G., Boschero, A. C., Hutton, J. C., Kawazu, S., Sener, A., Atwater, I. J., Duncan, G., Ribalet, B. \& Rojas, E. (1978) Ann. N. Y. Acad. Sci. 307, 562-582

Marcum, J. M., Dedman, J. R., Brinkley, B. R. \& Means, A. R. (1978) Proc. Natl. Acad. Sci. U.S.A. 75, 3771-3775

Naber, S. P., McDonald, J. M., Jarett, L., McDaniel, M. L., Ludvigsen, C. W. \& Lacy, P. E. (1980) Diabetologia 19, 439-444

Nishida, E., Kumagai, H., Ohtsuki, I. \& Sakai, H. (1979) J. Biochem. (Tokyo) 85, 1257-1266

Orr, H. T., Cohen, A. I. \& Lowry, O. H. (1976) J. Neurochem. 26, 609-611

Schubart, V. K., Fleischer, N. \& Erlichman, J. (1980) J. Biol. Chem. 255, 11063-11066

Schatzmann, J. H. (1973) J. Physiol. (London) 235, 551-569

Shibata, A., Ludvigsen, C. W., Naber, S. P., McDaniel, M. L. \& Lacy, P. E. (1976) Diabetes 25, 667-672
Simons, T. J. B. (1982) J. Membr. Biol. 66, 235-247

Sugden, M. C. \& Ashcroft, S. J. H. (1981) Biochem. J. $197,459-464$

Sugden, M. C., Christie, M. R. \& Ashcroft, S. J. H. (1979) FEBS Lett. 105, 95-100

Suzuki, S., Oka, H., Yasuda, H., Ikeda, M., Chen, P. Y. \& Oda, T. (1981) Biochem. Biophys. Res. Commun. 99, 987-993

Valverde, I., Vandermeers, A., Anjaneyula, R. \& Malaisse, W. J. (1979) Science 206, 225-227

Watterson, D. M., Harrelson, W. G., Jr., Keller, P. M., Sharef, F. \& Vanaman, T. C. (1976) J. Biol. Chem. 251, 4501-4513

Wollheim, C. B. \& Sharp, G. W. G. (1981) Physiol. Rev. 61, 914-973

Wright, P. H., Makulu, P. R., Vichick, D. \& Sussman, K. E. (1971) Diabetes 20, 33-45

Yaseen, M. A., Pedley, K. C. \& Howell, S. L. (1982) Biochem. J. 206, 81-87 